\title{
Endolymphatic Hydrops: Pathophysiology and Etiology
}

\author{
Sung-Il Nam \\ Department of Otolaryngology, School of Medicine, Keimyung University, Daegu, Korea
}

\section{내림프수종의 병인과 원인 질환}

\section{남 성 일}

계명대학교 의과대학 이비인후과학교실

\author{
Received May 29, 2011 \\ Accepted July 18, 2011 \\ Address for correspondence \\ Sung-Il Nam, MD \\ Department of Otolaryngology, \\ School of Medicine, \\ Keimyung University, \\ 56 Dalseong-ro, Jung-gu, \\ Daegu 700-712, Korea \\ Tel $+82-53-250-7715$ \\ Fax $+82-53-256-0325$ \\ E-mail entnamsi@dsmc.or.kr
}

Endolymphatic hydrops $(\mathrm{EH})$ represents a histopathologic finding in which the structures bounding the endolymphatic space are distended by an enlargement of endolymphatic volume. EH primarily involves the cochlear duct and saccule but can involve the utricle and ampullae of the semicircular canals. EH is a consistent finding in patients with Meniere's disease, however, the reverse is not true. EH may occur as a consequence of a variety of disorders, including DFNA 9, Alport syndrome, serous labyrinthitis, suppurative labyrinthitis, otosyphilis, temporal bone fracture, surgical trauma, neoplasm, immune disorders, otosclerosis, or Paget's disease. The mechanism of development of hydrops is also unclear. This review provides information to understand the recent pathophysiologic mechanism and causal disoders in $\mathrm{EH}$. Korean J Otorhinolaryngol-Head Neck Surg 2011;54:509-18

\section{서 론}

내림프수종(Endolymphatic hydrops)이란 증가된 내림프 액에 의하여 내림프강을 형성하는 구조물들이 팽창되어 나 타나는 병리 조직학적 소견이다. 이러한 소견은 1938년에 영 국의 Hallpike와 Cairns" 및 일본의 Yamakawa'가 개별적 으로 사람의 측두골 연구를 통하여 최초로 메니에르병의 내 이 조직병리는 내림프수종이라고 발표하였다.

지금까지 발표된 문헌에 의하면 메니에르병과 내림프수종 의 관계가 단순하고 밀접한 상관관계에만 있는 것은 아니 다. ${ }^{3-6)}$ 메니에르병 초기의 병리소견은 감각세포와 주변의 지 주세포들이 대부분 뚜렷하게 정상적인 소견을 나타내고, 메 니에르병 환자들이 호소하는 증상을 설명하기에는 역부족이 기 때문에 유일한 내림프수종의 관찰은 메니에르병의 중요한 원인으로 간주되어 왔다. ${ }^{3)}$ 그러나, Schuknecht와 Gulya ${ }^{6}$ 는 메니에르병이 없는 환자의 측두골에서도 내림프수종이 관찰 되고 이를 '무증상형 내림프수종'이라고 보고하였다. 그리고
Merchant 등 ${ }^{4}$ 은 963명의 측두골 병리 연구에서 메니에르병 으로 진단된 모든 환자에게 일관되게 내림프수종을 관찰하였 지만, 79 예의 내림프수종 중 28예는 메니에르 증상을 나타냈 다. 그리고 나머지 51예는 메니에르 증상을 나타내지 않아 내 림프수종이 메니에르병의 중요한 병리소견이지만, 메니에르 증상을 나타내는 데 직접적으로 관여하지는 않는다고 밝혔다.

메니에르병은 전체 어지럼 환자의 약 $10 \%$ 정도를 차지하 고 있지만, 메니에르병의 주된 병리소견인 내림프수종의 병 인들과 원인 질환들에 대해 정리된 문헌이 부족하고, 국내에 도 잘 알려져 있지 않아서 최근 보고된 문헌들을 중심으로 정 리하고 기술하려 한다.

\section{Pathophysiology of Endolymphatic Hydrops}

현재까지 내림프수종을 일으키는 기전은 명확히 밝혀지지 않았지만, 다수의 요인들이 제시되고 있다. 내림프의 과생성, 
내림프낭으로의 내림프 흡수장애, 내림프 압력의 증가, 전해질 불균형, 유전적 기형, 바이러스 감염, 자율신경계 이상, 식이 요소, 자가면역반응, 혈관 이상, 알레르기 반응 등이다.,7,8)

\section{종적 순환(Longitudinal flow)의 폐쇄}

내림프수종을 유발할 수 있는 대표적인 기전으로는 와우에 서 내림프낭까지 내림프 종적순환(longitudinal flow)의 폐 쇄가 널리 알려져 있다.,10) 내림프의 생성 및 흡수, 흐름에 대 해서는 많은 주장들이 보고되고 있는데, 와우의 혈관조에서 생성된 내림프가 연합관을 지나 내림프낭에서 흡수된다는 종적 순환설(longitudinal flow theory)과 전정미로 내의 검 은 세포와 반월면에서 내림프가 국소 생성 및 흡수 된다는 방사상 순환설(radial flow theory)이 있다. 이는 실험적으로 와우내에 색소를 주입할 때 색소가 내림프낭 내로 침착되는 것, ${ }^{10)}$ 내림프낭의 파괴나 내림프관의 폐쇄시 내림프수종이 유발된다는 간접적 증거를 통해 설명되고 있다. 그리고 이러 한 기전은 메니에르병에서 수술적 치료인 내림프낭 감압술의 이론적 근거가 되고 있다.

Salt는 동물(guinea pig) 실험에서 내림프 순환 속도를 측 정하였는데 내림프의 종적 순환 속도가 무시할 정도로 아주 늦기 때문에 guinea pig 모델에서 내림프수종을 설명하기에 는 역부족이며 새로운 흐름으로 미로막을 가로지르는 '확산 과정(diffusion process)'설을 보고하고 있다. ${ }^{11,12)}$ 더군다나 영 장류(靈長類)에서 수개월의 짧은 기간 동안의 림프관과 림프 낭의 폐쇄는 수종을 일으키지 않는다고 하며,13) 5 년 동안의 림 프낭의 폐쇄는 경도의 비 진행성 수종을 일으킨다고 한다. ${ }^{14)}$ 또 다른 기전으로 내림프낭이미다른 구조물 ${ }^{16}$ 과 연관된 과다 분비 기전이 있지만 여전히 결정적인 증거는 부족한 실정이다.

\section{내림프 압력의 증가}

Tonndorf ${ }^{17,18)}$ 는 내림프와 외림프 사이의 압력차이에 의해 내림프 고혈압(endolymphatic hypertension)이 발생하여 내 림프 수종이 생긴다고 보고하면서 이러한 소견은 메니에르병 시 나타나는 청력손실의 기전으로 설명하고 있다. 그러나 guinea pig 실험에 의하면 급성 내림프수종과 만성 내림프수종시 내 림프와 외림프액 사이에 압력 차이가 나타나긴 하지만 무시 해도 될 정도 $(<0.5 \mathrm{~mm} \mathrm{Hg})$ 의 변화가 생기고, 내림프 구조 물들간에 압력에 매우 잘 순응하는 기계적 순응도가 높기 때 문에 '내림프 고혈압'설은 올바르지 않다고 기술하고 있다. ${ }^{19-21)}$

\section{내림프 용량과 구성에 대한 조절기전}

내림프 용량과 구성에 대한 조절기전에 대해서는 아직 밝 혀지지 않은 실정이다. 만약 내림프액이 외림프액에 비해 고장
액이 되면, 결과적으로 삼투압에 의해 내림프 내로 물의 이동이 일어나서 내림프 용량이 증가되어 궁극적으로 내림프수종이 생길 수 있다.

내림프 조절에 관한 연구는 수분 통로 당백(aquaporin, $\mathrm{AQP}$ ) 이 발견된 후 내림프에서의 수분 이동 및 조절에 관심이 증가 되고 있다. 특히, $\mathrm{AQP}$ 수분 통로 가운데 $\mathrm{AQP} 2$ 는 신장의 집 뇨세관에 존재하면서 항이뇨 호르몬(arginine vasopressin) 의 조절하에 수분 재흡수를 담당하고, 체액량 감소에 반응하 여 수분 항상성을 유지한다. 또한 vasopressin은 urea transporter의 발현을 조절하는 것으로 보고되고 있다. ${ }^{22)}$ 그래서 urea는 삼투 차이를 야기시키는 물질이며, 특히 신집합관에서 물의 흐름을 조절하는 삼투질로 알려져 있다. 내이와 신장은 그 미세구조 및 기능면에서 흡사한 면이 많아 내이의 수분 조 절에도 $\mathrm{AQP} 2$ 가 밀접히 관련되어 있을 것으로 추정되며, 여러 연구에서 내림프의 주 조절기관인 내림프낭에서 vasopressin receptor와 AQP2가 발현됨이 보고되었다. ${ }^{23)}$ 이러한 소견을 바탕으로 한 동물 모델에서 vasopressin을 주입하여 내림프 수종을 만든 연구가 있는데 이는 내림프액 용량이 신장에서 와 유사한 기전으로 조절 받는 것으로 추정된다. ${ }^{24)}$ Urea transporter도 또한 내이에 존재하는 것으로 보고되고 있다. ${ }^{25)}$ $\mathrm{AQP} 2$ 가 vasopression 주입에 의하여 발현이 조절됨이 알려 져, 내이의 내림프 조절에도 vasopressin-AQP2 시스템이 관여 하고 있을 것으로 추정되지만 직접적으로 연관을 짓기에는 아직 연구가 부족한 실정이다.

\section{Morphological Characteristics of Hydrops}

메니에르병 초기에 내림프수종은 주로 와우관(cochlear duct) 과 구형낭(saccule)에 국한되어 관찰되나, 수종이 진행되면 난 형낭(utricle), 팽대부(ampulla) 및 전 내림프 시스템까지 침범 하게 된다. 심한 경우 Reissner막이 전정계(scala vestibule) 벽 에 부착될 수 있고, 구형낭 벽이 등골 족판을 포함한 반대편 전 정벽까지 신전하는 경우도 있다. 일반적으로 수종은 와우(cochlea)와 구형낭(saccule)이 다른 막구조인 난형낭과 팽대부 에 비해 좀 더 쉽게 팽창된 소견을 나타낸다. 그 이유로 첫째, 내이를 구성하는 막 자체의 기계적 순응(mechanical compliance), 내구력과 관계가 있다. 즉 구형낭은 높은 순응(기계적 으로는 약한 막)을 보이는 반면 난형낭은 낮은 순응을 보인 다. ${ }^{7)}$ 둘째, 반규관과 팽대부에 상대적으로 뻑뻑한 무정형 물 질(thick amorphous material)이 함유되어서 미로의 막들이 팽창에 대해 기계적인 저항이 가해지기 때문으로 추측된다. 


\section{Causal Diseases of Endolymphatic Hydrops}

내림프수종은 메니에르병과 같이 측두골에서 원인으로 간 주할만한 명확한 이상이 없는 경우인 idiopathic(원인미상)과 내이에 다른 병적인 변화가 같이 존재하는 secondary(이차성) 로 나눠진다.

와우 첨부에 발생한 내림프수종에 대한 몇 가지 보고가 있 다. Yamashita와 Schuknecht ${ }^{26)}$ 는 300명의 환자 중 495개 측두골에서 와우의 apical turn에 국한된 내림프수종만을 연구하였는데, 질환은 presbycusis, 이경화증, 중이염, 비병리 적 와우였다. 전체적 발생률은 $15.8 \%$ 였지만 상기 네 군 사이 에서 중요한 차이들은 발견되지 않았으며, 결론적으로 와우 첨부에만 발생한 내림프수종은 병리적으로 혹은 기능적으로 는 이상이 없다고 보고하였다. Lau와 Linthicum ${ }^{27)}$ 은 컴퓨터을 통한 와우 첨부를 3차원적으로 재현(computer aided threedimensional reconstruction)하였고 14 명의 정상 측두골을 연구하였는데 첨부에서의 Reissner's membrane 확장은 어 떤 와우관 면을 어떻게 절단하느냐에 따라 다르게 나타나기 때문에 수종이라기보다는 정상이라고 보고하였다.

\section{DFNA 9}

DFNA9은 20 50대에 시작하여 점진적으로 악화되는 감각 신경성 난청과 평형장애를 보이는 질환으로써, coagulation factor $\mathrm{C}$ homology $(\mathrm{COCH})$ 유전자의 돌연변이에 의해 발생 한다. $\mathrm{COCH}$ 유전자는 14번 염색체의 장완(14q12-q13)에 위치 하는 유전자로서, 12 개의 엑손으로 구성되며 cochlin이라는 단백질을 암호화한다. ${ }^{28-30)}$ 초기에는 고주파수 영역에서 난청 이 시작되어 연령이 높아질수록 전 주파수 영역으로 확대되면 서 심도 난청까지 진행한다. 전정기능 저하도 난청과 유사하며 연령이 많아질수록 심해지며 가벼운 어지럼증부터 현훈발작 에 이르기까지 다양한 증상을 나타낸다. ${ }^{31)} \mathrm{DFNA9}$ 은 난청과
함께 다양한 정도의 현기증을 함께 동반하는 경우가 많아 메 니에르병과의 감별이 필요하다. $\mathrm{COCH}$ 유전자와 메니에르 증 상과의 관계에 대한 몇 개의 보고가 있다. ${ }^{32,33)}$

병리학적인 특징으로는 경도에서 중등도의 내림프수종이 가끔 와우에서 관찰되지만 일관된 소견은 아니며 나선상 인 대의 변성과 호산성물질의 퇴적물을 전정기관에서 찾을 수 있다. ${ }^{34)}$

\section{Alport syndrome}

Alport 증후군은 1927 년 Alport ${ }^{35)}$ 에 의해 처음 보고된 질환 으로서 혈뇨를 주증상으로 하는 유전성 신장질환과 함께 10 대 이후부터 점진적으로 진행되는 감각신경성 난청 및 안구의 병변을 동반하게 된다. 원인은 제4형 교원질을 형성하는 유전 자(COL4A3, COL4A4, COL4A5)의 변이에 의한 것으로 알려 져 있다. ${ }^{36)}$ 청력장애는 대개 20대에서 시작되어 점진적으로 진 행하는 양측성의 감각신경성 난청이 나타나게 되며, 대개 60 $70 \mathrm{~dB}$ 은 초과하지 않는 것으로 보고 되고 어음명료도는 정상 이며, 미로성 난청의 소견을 보인다. 청력도는 flat, downslope 혹은 trough-shaped 패턴을 보인다. 병리학적 소견은 다양하 게 보고되고 있는데 Fujita와 Hayden ${ }^{37)}$ 은 와우 구조물에 특 별한 병변을 관찰할 수 없다고 하였고, Merchant 등히은 와 우의 병변을 주로 기술하였는데 Organ of Corti의 basement membrane이 분리되고 들어 올려져 있으며, tunnel of Corti와 Nuel 공간에 세포들로 메워져 있다. 내림프수종도 볼 수 있 으나 항상 일관되게 나타나는 소견은 아니라고 기술하고 있 다(Fig. 1).

\section{장액성 미로염(Serous labyrinthitis)}

장액성 미로염은 급성 화농성 중이염의 가장 빈번한 합병증 의 하나이다. 내이에 세균 침범 없이 감염되거나 염증 부산물 등의 독성물질이 정원창, 난원창륜 또는 미로누공을 통하여 내이로 침입한다. 평형이상이 난청보다 수 시간 또는 수일 전에
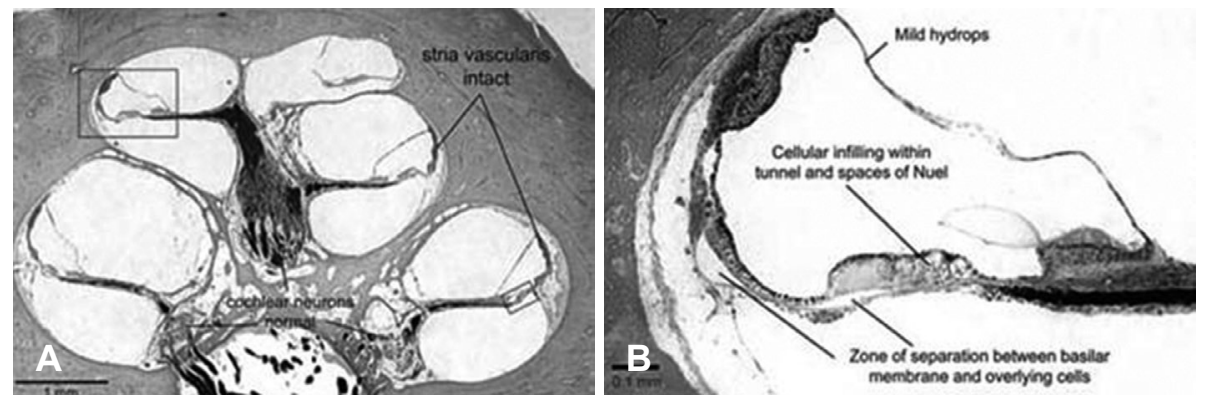

Fig. 1. Alport Syndrome. Midmodiolar section through the left cochlea showing normal population of the cochlear neurons and normal appearing stria vascularis throughout the cochlea. Areas marked by boxe is shown at higher magnification in B (A). Scala media of upper middle turn, showing a zone of separation between the basilar membrane and overlying cells of the organ of Corti, cellular infilling within the tunnel of Corti and spaces of Nuel, and mild endolymphatic hydrops. The stria vascularis shows mild atrophy. The tectorial membrane and spiral limbus appear normal ${ }^{38)}(B)$. 
나타나며, 어지러움과 구토를 호소하고 안진 소견을 보일 수 있다. 청력검사에서 경도 또는 중등도의 고주파 감각신경성 난청을 보인다. 수개월 또는 수년에 걸쳐서 반복되는 일과성 현기증을 호소하며 변동성 감각신경성 난청을 보이는 경우도 있다. 급성 장액성 미로염의 주된 측두골 병리조직 소견으로 경도에서 중등도의 내림프수종이 발생할 수 있으며, 미세 섬 유(fine fibrillar) 혹은 과립 침전물(granular precipitate)이 내이 림프액 내에 출현하는 소견을 나타낸다. ${ }^{39)}$

\section{화농성 미로염(Suppurative labyrinthitis)}

세균이 직접 내이, 즉 막미로 안으로 침입한 것을 의미한다. 염증의 전파경로는 고실성 미로염(tympanogenic labyrinthitis), 수막성 미로염(menigogenic labyrinthitis), 혈행성 미로염 (hematogenous labyrinthitis)의 세 가지 경로가 있다. 화농성 미로염은 급격하고 심한 내이증상이 나타나며, 내이기능의 급 격한 손실로 심한 현기증, 구토, 자발안진, 감각신경성 난청이 돌발적으로 발생한다. Schuknecht ${ }^{39)}$ 는 화농성 미로염의 조 직학적 변화를 4단계로 구분하고 있는데, 첫째, 다형백혈구의 침윤 시기, 둘째, 내림프수종이 생기는 시기, 셋째, 막성 내이의 괴사, 넷째, 섬유화와 신생골 형성이다.

\section{이성 매독(Otosyphilis)}

이성 매독은 선천성 감염이나 후천성 감염으로 인해 발생한 다. 점차적인 내림프수종을 일으키는 대표적인 질환들은 메 니에르병과 이성 매독이라 할 수 있다. 이 두 질환의 병리학적 조직소견 및 난청과 현훈의 임상적인 양상은 서로 유사한 것으 로 알려져 있다. 이성 매독에서 내림프수종이 생기는 기전으 로 미로 골염(labyrinthine osteitis)이 있다. 그리고 Linthicum 과 el-Rahman ${ }^{40)}$ 은 수종 발생의 기전을 military gummata와 내림프관의 골염이라고 보고하였다. 그러나 Miller 등 니는 otosyphilis 8명 환자 중 11개 temporal bone으로 이성 매독 과 내림프수종과의 관계에 대해 조직병리학 연구를 하였다. 모든 case에서 cochlea, saccule 그리고 utricle에서 다양한 정도의 내림프수종이 관찰되었으나, 골염 소견이 모든 예에서
나타난 것은 아니다. 그래서 이성 매독에서 내림프수종의 생기 는 기전으로 미로 골염 외에 여러요소들이 관여할 것으로 보고 하였다. 내림프수종외의 소견으로 원형세포 침윤, microgum$\mathrm{ma}$ 형성, 골이 흡수된 부분에는 골수, 지방조직과 신생골 형 성, spiral ganglion, Organ of Corti 그리고 stria vascularis 는 다양하게 위축되는 소견을 나타냈다(Fig. 2).

\section{측두골 횡골절(Transverse fracture)}

측두골 횡골절은 추체축과 골절선이 직각을 이루는 골절형 태로서 측두골 골절의 10 20\%를 차지한다. 이낭(otic capsule) 골절은 심한 전정계 이상과 난청을 초래하여 즉각적인 감각 신경성 난청과 현훈을 동반하는 것이 일반적이다. 측두골 골 절 후 생긴 내림프수종에 대한 문헌들이 몇 예 있다. $\mathrm{Pulec}^{42)}$ 은 16세 소년이 두개저 골절이 있었으나 수상 당시에는 난청 이 없었고, 방사선 검사상 골절선이 전정도수관(vestibular aqueduct)을 지나가는 소견이었다. 수상 6주 후 소년은 측두 골 골절된 쪽에서 이명과 현훈을 동반한 저음역의 변동성 난 청이 나타났다고 기술하였다. Clark과 Rees ${ }^{43}$ 는 22 세 여자 환 자가 두개저 골절을 수상한 후 5개월 후 이명, 이충만감과 변 동성 저음역 감각신경성 난청을 나타내었고, Glycerol 검사상 양성소견을 나타냈다고 보고하였다. Rizvi와 $\mathrm{Gibbin}^{44)}$ 은 5명 횡골절 측두골 조직병리를 연구하였는데, 4명에서 전정도수 관에 골절이 있었고, 이 4 명 중 2명이 내림프관이 완전히 폐쇄 되는 소견을 보였다. 이 2 명 중 1명에서 막미로는 정상이었고 심한 내림프수종을 나타내었고, 나머지 4명은 막미로가 파열 되고 내림프수종은 없었다. 이러한 소견들은 횡골절 후에 전 정도수관 폐쇄로 인해 내림프수종이 일어날 수 있지만, 메니 에르 증상을 일으킬만한 청각전정 상피와 뉴런이 존재할 때 가능한 것으로 보고하였다. Lyos 등 ${ }^{45}$ 은 측두골 횡골절 후에 생기는 점진적인 감각신경성 난청의 기전으로 전정도수관의 침범에 의한 이차적 내림프수종과 외림프누공일 가능성에 대 해 기술하였다. 수종외의 소견으로 감각신경성 구조물들의 변 성, 막미로 벽의 파열 등의 소견들이 관찰된다.
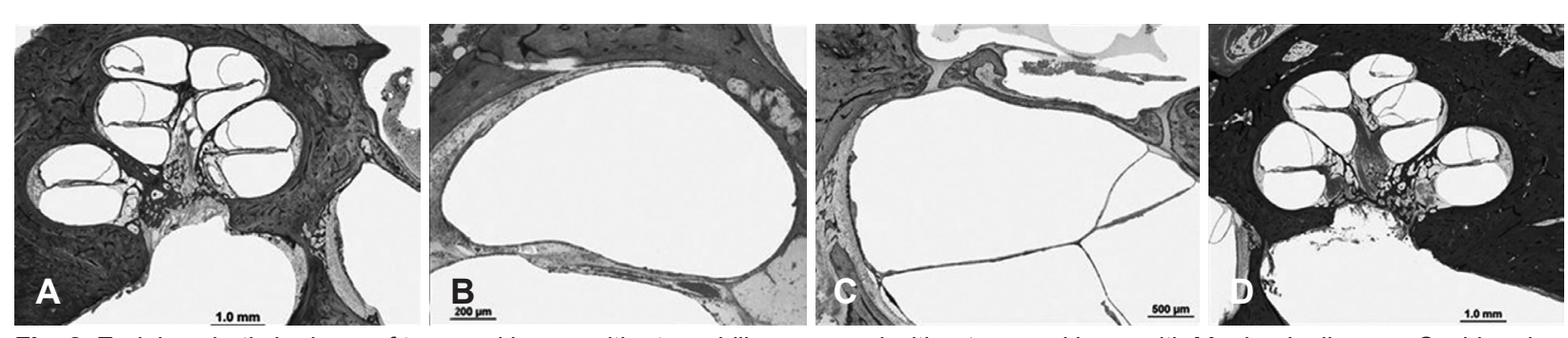

Fig. 2. Endolymphatic hydrops of temporal bones with otosyphilis compared with a temporal bone with Meniere's disease. Cochlear hydrops (A). Severe cochlear hydrops with Reissner membrane contacting the modiolus (B). Saccular hydrops with membrane abutting stapes footplate (C). Comparison case of cochlear hydrops in Meniere's disease ${ }^{41)}(D)$. 
등골 절제술(Stapedectomy)

Belal과 Ylikoski ${ }^{46}$ 는 한측 혹은 양측 등골 수술을 받은 환자 중 오랜기간 동안 지속되는 어지럼증을 연구하였다. 등 골 절제술을 받은 117예 측두골 중 9예(8\%)에서 오랜기간 동 안 어지럼증이 지속되었으며, 병인은 화농성 미로염 1예, 내 림프수종 2예, 난형낭 내 섬유성 유착 2예, 구형낭 내 골절편 1 예, 진단 안된 청신경종 1 예였고, 나머지 2명은 정상적인 전 정구조를 나타냈다(Fig. 3).

\section{인공와우이식술(Cochlear implantation)}

Handzel 등 ${ }^{47}$ 은 인공와우 수술을 받은 17 개 측두골 조직 병리 연구에서 10개(59\%) 측두골에서 와우 수종(cochlea hydrops)을 나타내었으며 이런 경우에 대부분이 구형낭에도 허탈 소견을 나타냈다. 내림프수종을 나타낸 10예의 병력을 살펴보면 메니에르와 유사한 증상을 나타냈으며, 이러한 수 종을 일으킨 원인은 막미로 폐쇄보다는 측면 와우벽 손상의 결과로 초래된 것으로 보고하고 있다. 상기 소견들은 인공와

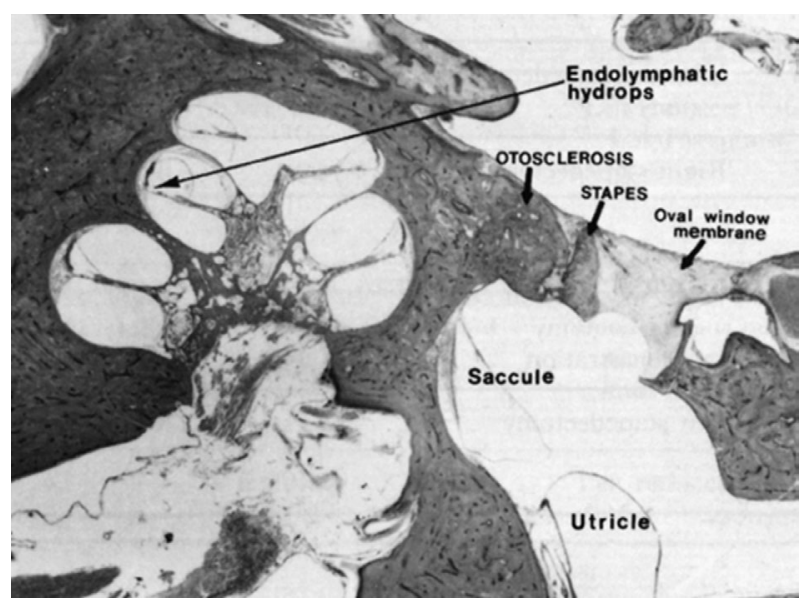

Fig. 3. Stapedectomy, complicated by postoperative cochlea enolympahtic hydrops. Right temporal bone shows severe endolymphatic hydrops of the middle coil of the cochlea. ${ }^{46)}$
우이식술 후 생긴 지연성 메니에르병 증상을 뒷받침해 줄 수 있는 기전이라고 설명하였다(Fig. 4).

\section{Endolymphatic sac tumor}

내림프낭 종양에서 대표적 이과적 병리소견으로는 내림프 수종을 꼽을 수 있다. ${ }^{48)}$ 내림프낭 종양은 단독으로 생길수도 있으나 Von Hippel-Lindau 증후군 환자인 경우 약 $15 \%$ 정도 로 내림프낭 종양과 같이 발생한다. Butman 등 ${ }^{49}$ 은 방사선 학 검사와 임상적 소견을 바탕으로 내림프낭 종양환자에서 난청의 기전으로 첫째, 종양의 직접적인 이낭 침범 둘째, 미로 내 출혈, 셋째, 내림프수종이라고 기술하면서, 서서히 진행되 는 난청의 원인으로는 내림프수종이라고 결론짓고 있다. Lonser 등이은 방사선학적으로 내림프낭에서 발견되지 않는 미세 종양인 경우 첫 증상으로 메니에르병과 유사한 증상으 로 나타날 수 있다고 보고하고 있다(Fig. 5).

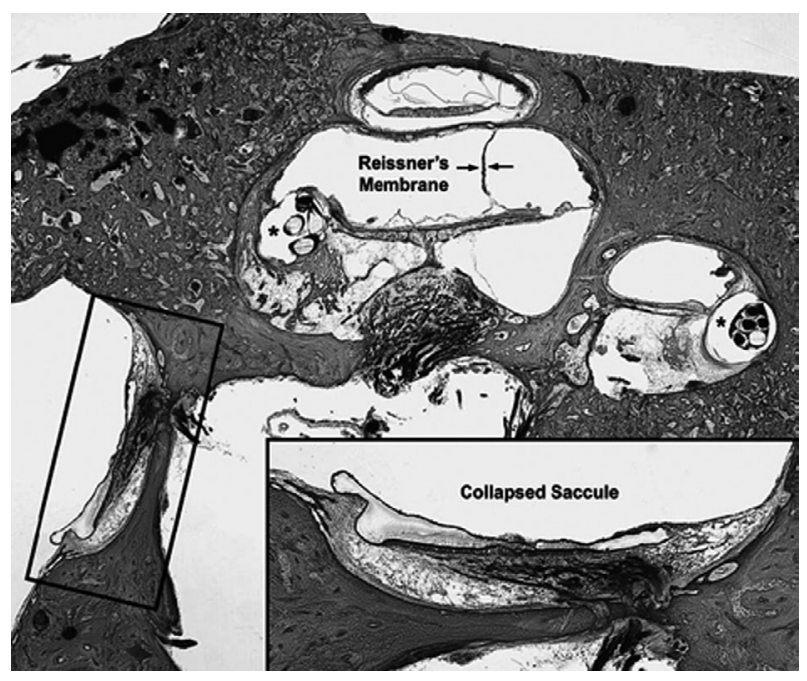

Fig. 4. Cochlea hydorps after cochlear implantation. Reissner membranes of the ascending and descending limbs of the basal turn of cochlea were distended and abutted each other (arrow). The saccule was collapsed. Inset demonstrates the saccular membrane lying against part of the neuroepithelium. *electrode array. ${ }^{47)}$
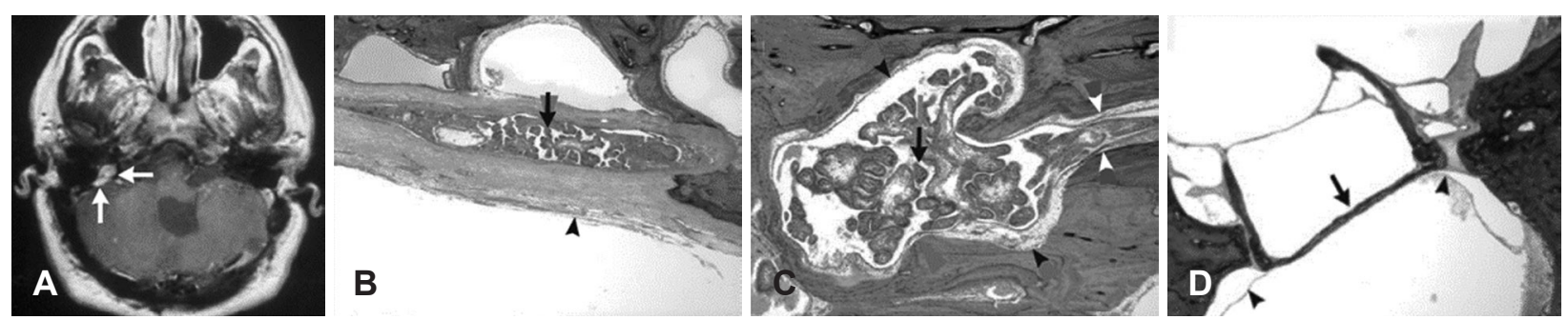

Fig. 5. Tumors of the Endolymphatic sac in von Hippel-Lindau disease. The axial T1-weighted, contrast-enhanced MRI scan in Panel. (A) reveals an enhancing endolymphatic-sac tumor in the right temporal bone (arrows). Despite the patient's bilateral hearing loss, no abnormality was evident in the left temporal region. Sections of temporal bone show papillary tumors in both endolymphatic sacs. (B) (hematoxylin and eosin, $\times 5$ ) shows, the left endolymphatic-sac tumor (arrow) extends from the endolymphatic duct into the endolymphatic sac, which is contained within the posterior fossa dura (arrowhead). (C)(hematoxylin and eosin, $\times 20$ ), the endolymphatic sac tumor in the left temporal bone (arrow) is within the duct (white arrowheads) and has eroded the contiguous region (black arrowheads). (D)(hematoxylin and eosin, $\times 10$ ), distention of the saccular membrane indicates endolymphatic hydrops. The distended saccule (arrowheads) adheres to the undersurface of the footplate of the stapes (arrow) ${ }^{50)}$ MRI: magnetic resonance imaging. 


\section{Cochleovestibular schwannoma}

Mahmud 등 ${ }^{11}$ 은 수술하지 않은 한측 전정신경초종 11예에 대해 측두골 병리조직을 연구하였는데, 전정신경초종은 내이 에 직접적인 침범 없이도 Corti기, 혈관선조, 청신경세포에 광 범위한 변성을 초래하였으며, 그 기전은 명확하지 않지만 사이 토카인이나 독성이 있는 분자물질이 내이에 유리되어 생긴다 고 한다. ${ }^{52)}$ 또한 미로의 침범 없이 내이도 내에만 전정신경초종 이 존재하더라도 호산구성 침전물이 내이의 공간에 축적되거나 내림프수종이 약 $30 \%$ 정도 생긴다고 보고하고 있다(Fig. 6). ${ }^{51)}$

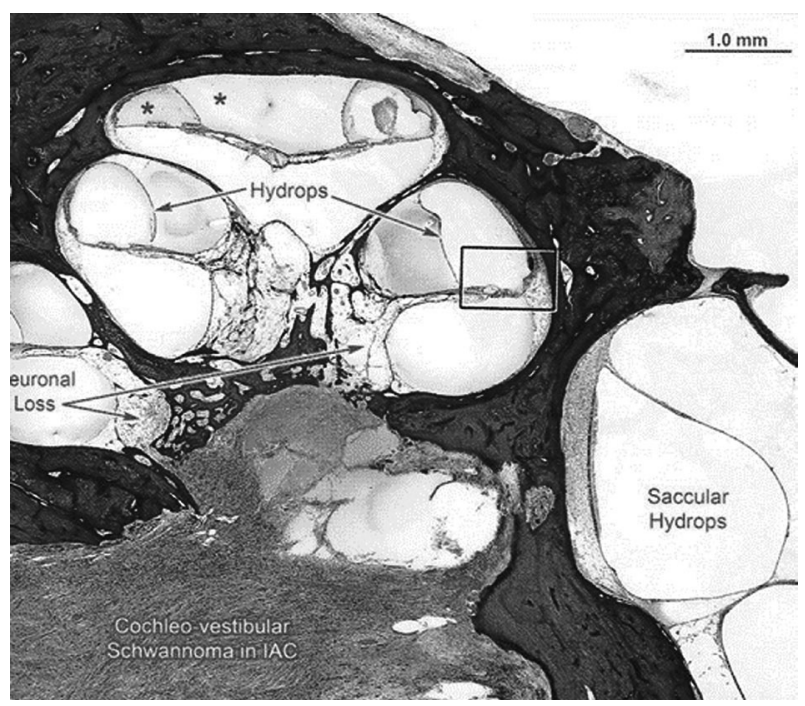

Fig. 6. Endolymphatic hydrops by cochleovestibular schwannoma. The right temporal bone showed a schwannoma within the internal auditory canal (IAC) involving the vestibular and cochlear nerves. There was endolymphatic hydrops involving the cochlea and saccule, as well as an acidophilic-staining precipitate (shown by $^{*}$ ) within the endolymphatic and perilymphatic spaces throughout the labyrinth. ${ }^{51)}$

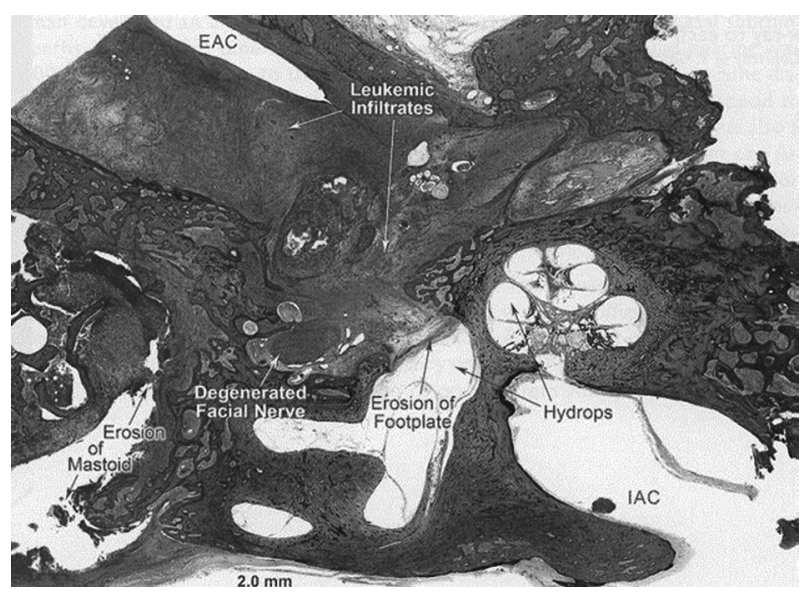

Fig. 7. Endolymphatic hydrops by Myelocytic leukemia. Erosive granular mass in the left external auditory canal and middle ear. The left temporal bone showed massive invasion by a destructive leukemic infiltrate. The inner ear showed severe endolymphatic hydrops (adapted from Schuknecht's Pathology of the Ear, 3rd Ed.). EAC: external auditory canal, IAC: internal auditory canal.

\section{Leukemia}

백혈병 환자에서의 난청은 Donne ${ }^{53)}$ 에 의해 처음 기술되었고, Politzer $^{54}$ 는 내이의 조직학적 소견이 막미로의 변성과 와우 내의 신생골 생성이라고 처음으로 소개하였다. 백혈병 환자의 일관된 조직소견으로는 intense leukemic 침윤과 추체부의 골 수가 백혈병 세포로의 대체 소견이다. Sando와 Egami ${ }^{55)}$ 는 돌발성 난청을 동반한 만성림프성 백혈병 환자에서 조직병리 연구를 하였다. 주된 소견으로 첫째, 내림프강과 외림프강에 모두 백혈병 출혈, 둘째, 와우와 구형낭의 내림프수종, 셋째, 전정도수관과 내림프낭이 비교적 좁아지고 바르게 펴진 소 견을 보였다. 그래서 와우내로의 출혈이 돌발성 난청과 평형 장애의 원인이라고 추측하고 있다(Fig. 7).

\section{Immune Disorders}

면역성 내이질환이 일차적이든 혹은 이차적이든 이과적 병리소견은 비슷하다. 즉, 청각과 전정미로에서의 감각세포와 신경세포의 변성과 파괴, 내림프수종, 신생골과 섬유조직의 축적, 내이내의 분산된 림프구 침윤 소견을 나타낸다.

\section{Prmary immune mediated inner ear disease}

Yoo 등 ${ }^{56,57)}$ 은 메니에르병과 이경화증 환자의 혈청에서 제 2 형 콜라젠에 대한 항체가 증가되어 있음을 발견하였다. 또한 제 2 형 콜라젠으로 감작시킨 흰쥐의 내이에서 병리조직학적 변화를 관찰하여 제 2 형 콜라젠이 면역매개성 내이질환의 중 요한 항원단백질임을 시사하였다. 감각신경성 난청과 메니에르 병 환자들의 혈청에서 $68 \mathrm{kD}$ 내이항원에 대한 항체를 관찰하 고 $68 \mathrm{kD}$ 단백질이 면역매개성 내이질환의 중요한 항원일 수 도 있다고 하였다. Hughes 등 ${ }^{58}$ 은 5 년 동안 자가면역 내림프 수종에 관한 연구를 통해서 52 명의 자가면역 내이질환으로 진 단 받은 환자 중 27 명 $(52 \%)$ 이 내림프수종을 나타냈다고 기술 하였다. 면역매개성 내이질환의 이과적 병리에 대한 문헌은 현 재 부족한 실정이다. Massachusetts eye and ear infirmary 표 본을 참고로 하면 와우와 전정기관에 광범위한 림프구 침윤이 있으며 섬유-골 조직의 침착과 내림프수종의 소견을 보였다.

\section{결절성 다발 동맥염 (Polyarteritis Nodosa)}

결절성 다발 동맥염(polyarteritis nodosa)은 중요장기에 피 를 공급해 주는 동맥에 염증을 일으켜 피의 공급이 원활치 못 하게 되어 장기에 손상을 주는 질환으로서, 주로 작은(small) 그리고 중간(medium) 크기의 근육동맥에 다발성으로 괴사 


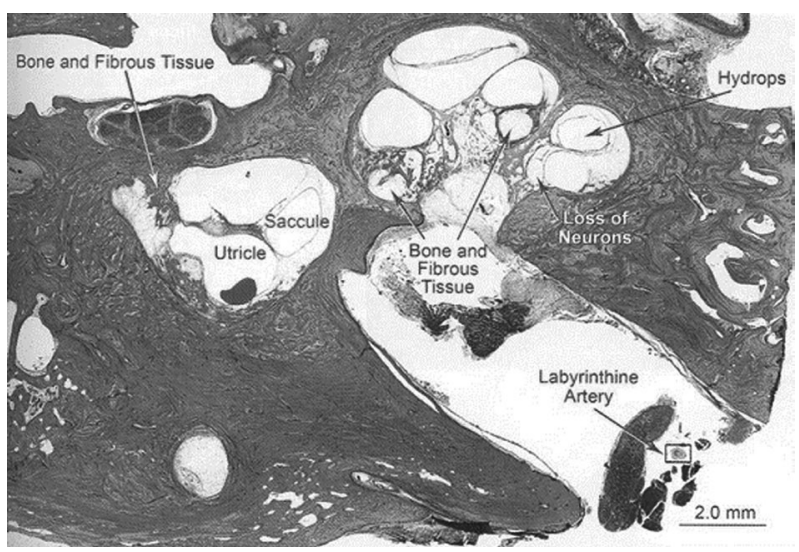

Fig. 8. Polyarteritis nodosa. The cochlea showed ischemic necrosis of soft tissue structures with extensive fibrosis and new bone formation. There was endolymphatic hydrops of the basal turn. There was total absence of the organ of Corti, stria vascularis, and cochlear neurons (adapted from Schuknecht's Pathology of the Ear, 3rd Ed.).

성 혈관염을 일으킨다. 질환의 심한 정도의 차이는 있겠지만 보고된 측두골 병리학적 소견은 다음과 같다. ${ }^{59-62)}$ 1) 미로 동 맥의 혈관염: 와우와 전정미로의 허혈성 괴사 2) 와우 신경세 포의 변성 3) 내이의 골과 섬유조직의 증식 4) 혈관선조의 위 축 5) 내림프수종: 광범위하게 동맥들을 침범하기 때문에 무 수히 많은 증상들이 있다. 즉, 불안감, 체중감소, 발열, 거식증, 관절염, 신경병증, 고혈압, 복부통증, 신부전 등이 올 수 있다. 이과적 증상으로는 감각성신경성 난청이 초기증상으로 혹은 말기에도 나타날 수 있으며, 하강형의 청력도를 보이며 빨리 진행하는 것으로 보고되고 있다(Fig. 8).

\section{Cogan's syndrome}

Cogan 증후군은 청각 및 전정기능 이상, 비매독성 간질성 각 막염을 특징적인 증상으로 나타내는 질환으로 원인은 확실하 지 않으나 자가면역 질환으로 추정하고 있다. 측두골에 대한 문헌은 5편이 있으며 심한 정도는 다소 차이가 있지만 병리학 적 소견은 유사하다. ${ }^{63-67)}$ 특징적인 내이 소견은 와우관(Corti 기와 혈관선조)과 전정미로(평형반, cristae, membranous wall) 의 광범위한 소실과 변성, 내림프수종, 내이내에 신생골과 섬 유조직 축적이다.

\section{Ulcerative colitis}

궤양성 대장염은 전 대장에 파급되는 점막에 국한되어 발생 하는 재발성 질환이다. 또한 여러 가지 임상양상을 갖는 다유 전적 질환이며 면역 조절 이상에 의해 발생한다고 알려져 있 다. 궤양성 대장염 질환의 장외(extra-intestinal) 소견으로 감 각신경성 난청을 일으킨다는 문헌들이 있다. ${ }^{68-70)}$ 난청은 주로 갑자기 혹은 급격히 진행되는 경향이 있으며, 종종 전정계 증

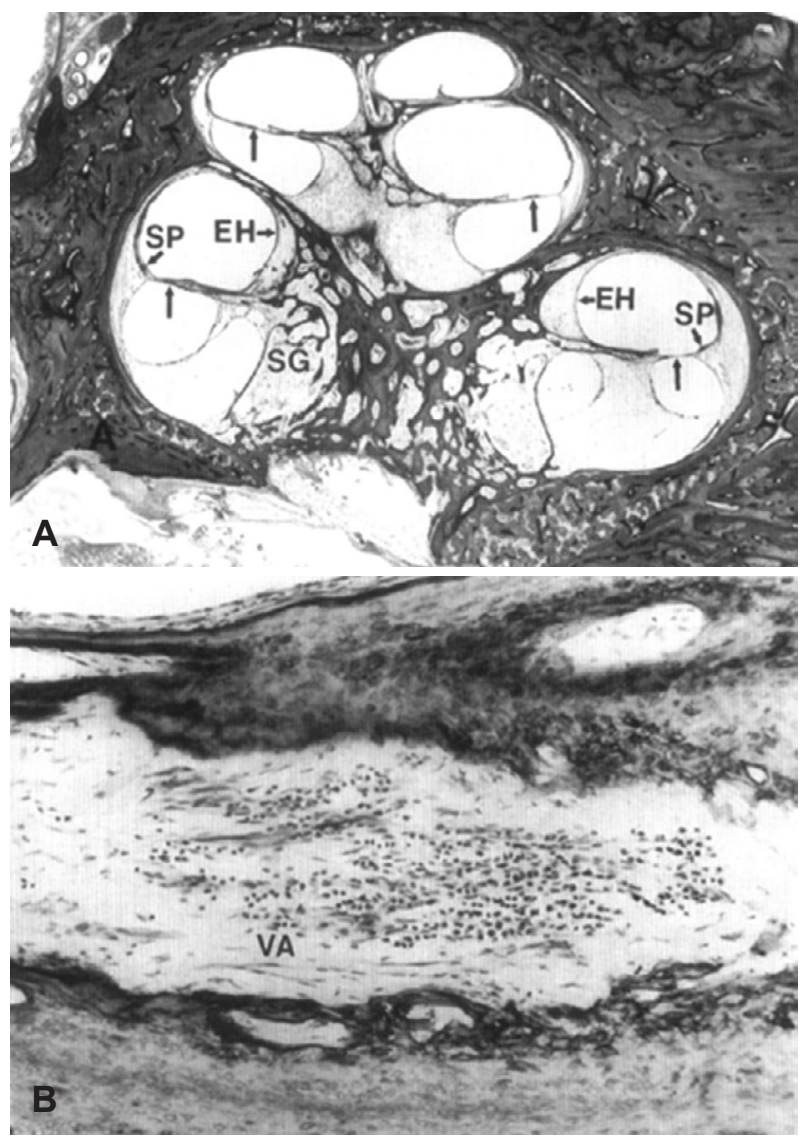

Fig. 9. A patient whose clinical history of ulcerative colitis, leukemia, and sensorineural hearing loss. Note loss of organ of Corti on the left (arrows), and endolymphatic hydrops $(\mathrm{EH})$ in all turns of the cochlea. Spiral ganglia (SG) are fewer and infiltrated with lymphocytes. Portions of the spiral prominence (SP) are missing (A). There is marked fibrosis and lymphocytic infiltration of the vestibular aqueduct $(\mathrm{VA})^{71)}(\mathrm{B})$

상(vestibular symptom)을 동반한다. 그리고 양측이 대부분 이환되며, 비록 한 측이 이환되더라도 수주 혹은 몇 개월 후에 는 반대편 귀에도 난청이 오는 것으로 되어 있다. 병리학적 소 견으로 Corti와 와우세포의 소실, 내림프수종, 그리고 섬유골조직의 축적과 미로내 림프구 축적을 나타낸다(Fig. 9). ${ }^{71)}$

\section{Bone Disorders}

\section{이경화증(Otosclerosis)}

이경화증은 골미로 bony labyrinth의 한정된 부분에 비정 상적인 골형성이 발생하는 질환으로, 상염색체 우성 유전양식 을 지닌다. 침범하는 부위는 전창소열 fissula ante fenestram (96\%)이 가장 흔하고 다음으로 정원창(30\%), 와우첨부(12\%), 난원창 후부(11\%), 내이도 후벽(5\%), 내이도 전벽(5\%), 와우도 수관 주위(3\%), 반고리관(2.4\%) 그리고 등족골 안면(1.6\%)의 순서로 침범하게 된다. ${ }^{72)}$ 시간 순서에 따라 2기로 나누어 볼 수 


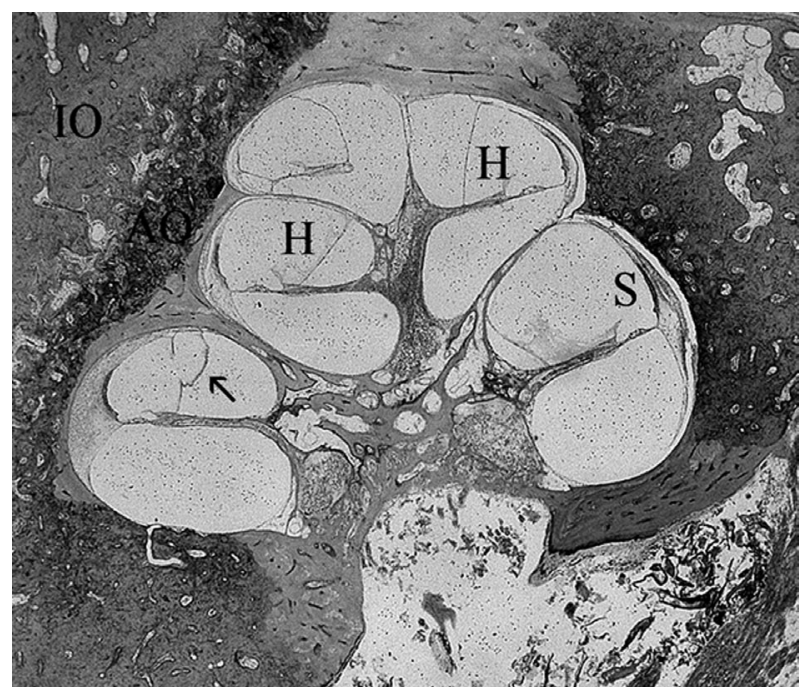

Fig. 10. Otosclerosis. Active otosponsigosis (AO), inactive otosclerosis $(\mathrm{IO})$, endolymphatic hydrops $(\mathrm{H})$, outpouches of Reissner's membrane (arrow), normal stria vascularis $(\mathrm{S}) .{ }^{77)}$

있는데 초기는 해면화(spongiosis)의 시기로 혈관주위 골조 직이 흡수되어 혈관 주위 공간이 확장되며 골파괴형 거대세 포에 의해 골조직이 더욱 흡수되고 섬유아세포가 골아세포 로 변형되어 기저물질은 풍부하고 교원질이 부족한 미성숙골 을 만들게 되며 이런 부분들은 호염기성을 띠게 된다. 후기는 경화(sclerosis)의 시기로 교원질이 보다 많고 기저물질은 줄어 든 좀 더 성숙한 골조직이 형성되며 이런 부분들은 호산성을 띠게 된다. 병변 내에서 불규칙한 속도와 시간대에 일어나게 되며 한 부위 내에서 이런 초기와 후기 병변이 동시에 진행하 여 호염기성과 호산성의 골 구획들이 섞여 나타나기도 한다. ${ }^{72-75)}$ 드물게 전정도수관을 침범하는 경우는 내림프수종이 발생할 수 있지만 ${ }^{76)}$ 전종도수관을 침범하지 않더라도 내림프수종이 발생하는 경우도 있다(Fig. 10). ${ }^{77,78)}$

\section{Paget씨 병}

Paget씨 병은 비정상적인 골의 흡수와 재형성을 특징으로 하는 만성적인 골대사 질환이다. 원인은 정확히 밝혀져 있지 않으며, 병리적인 과정은 과도한 파골 세포의 골흡수가 시작 된 후에 보상적으로 골모 세포의 새로운 골 형성이 이어지는 것이다. 새로 형성된 파제트 뼈는 구조적으로 무질서하며, 기 형과 골절에 더욱 취약하다. 두개골이 약 $70 \%$ 로 침범이 되며 이 중 약 $50 \%$ 정도가 난청을 동반하게 된다. 두개골을 침범 하게 되면 외이도 폐쇄를 일으키기 쉬우므로 전음성 난청을 야기할 수 있다. Paget씨 병은 1877년 James Paget에 의해 처 음 기술되었지만 정확한 난청의 기전에 대해서는 아직 명확하 지 않다. 주로 감각신경성 혹은 혼합성 난청의 형태로 나타나 고, 드물게 전음성 난청이 발생하기도 한다. 감각신경성 난청
은 고음역에서 나타나는 반면, 전음성 난청은 저음역에서 나 타나는 경향이 있다. ${ }^{79)}$ 난청의 발생 기전으로 추골 혹은 침골 의 고정, 등골의 고정 혹은 흡수, 유모세포의 소실, 청각 신경절 세포 소실, 내림프수종, 와우 골화, 골밀도의 변화, 이차적인 청신경의 압박 및 견인, 미세 골절 등이 제기되어 왔으나, ${ }^{80-82)}$ 최근 연구에 따르면 주로 와우의 기저부에 나선형 인대의 낭포 성 변성이 Paget씨 병의 감각신경성 난청을 초래할 수 있다고 보고하고 있다. ${ }^{83)}$

\section{Symptoms of Endolymphatic Hydrops}

내림프수종을 나타내는 원인질환들의 환자 병력의 기록들 을 보면 다양한 정도의 감각신경성 난청을 나타낸다.) 즉, 난청 은 저주파수 혹은 고주파수에서도 나타날수 있으며, 변동성 일수도 혹은 변동성이 아닐수도 있다. 다시 말해서 내림프수 종이 반드시 저주파수에서 그리고 변동성 난청과 자동적으 로 연관된 것은 아니라는 것이다. 메니에르병에서 볼 수 있는 현기증 발작은 내림프수종과 연관되어 있다는 것은 많이 알려 져 있는 사실이지만 광범위한 수종이 있음에도 불구하고 현 기증 발작이 없는 경우도 있었다. ${ }^{4)}$ Linthicum ${ }^{84)}$ 은 81예 측두 골 중 6예에서, 현기증 발작이 없었고 난청은 변동성이 아니라 점진적으로 나빠져서 난청의 정도는 경도난청에서 심도난청까 지 다양하였다고 보고하였다.

\section{맺 음 말}

지금까지 내림프수종의 병인론에 대한 동물 실험적 관찰 은 내림프수종을 이해하는 데 도움을 주고 있다. Hallpike와 Cairns 및 Yamakawa에 의해 내림프수종이 메니에르병 내이 의 주된 병인이라고 처음 소개되어지고 내림프수종이 메니에 르 증상을 나타낸다는 central 가설이 보고되어 왔다. 그러 나 부단 없는 측두골 병인의 많은 연구로 인해 내림프수종이 메니에르병의 일관된 병리조직소견이지만, 반대로 내림프수 종이 반드시 메니에르 증상을 일으키는 것도 아니며 여러질 환에서도 나타난다는 사실을 알게 되었다. 앞으로도 계속될 이비인후과 의사와 연구자들의 메니에르 증상을 나타내는 질 환에 대한 끊임없는 관심과 측두골 연구 및 내이 생리에 대 한 동물적 실험은 내림프수종이 어떤 기전에 의해 발생되었 는가에 대한 설명이 좀 더 구체화 될 것으로 기대한다.

\section{REFERENCES}

1) Hallpike CS, Cairns H. Observations on the Pathology of Ménière's Syndrome. J Laryngol Otol 1938;53(10):625-55.

2) Yamakawa K. Über die pathologische Veränderung bei einem Mé- 
nière -Kranken. J Otorhinolaryngol Soc Jpn 1938;44:2310-2.

3) Kiang NYS. An auditorium physiologist's view of Ménière's syndrome. In: Nadol JB Jr, editor. Second International Symposium on Ménière's disease. Amsterdam: Kugler \& Ghedini;1989. p.13-24.

4) Merchant SN, Adams JC, Nadol JB Jr. Pathophysiology of Meniere's syndrome: are symptoms caused by endolymphatic hydrops? Otol Neurotol 2005;26(1):74-81.

5) Rauch SD, Merchant SN, Thedinger BA. Meniere's syndrome and endolymphatic hydrops. Double-blind temporal bone study. Ann Otol Rhinol Laryngol 1989;98(11):873-83.

6) Schuknecht HF, Gulya AJ. Endolymphatic hydrops. An overview and classification. Ann Otol Rhinol Laryngol Suppl 1983;106:1-20.

7) Wit HP, Warmerdam TJ, Albers FW. Measurement of the mechanical compliance of the endolymphatic compartments in the guinea pig. Hear Res 2000;145(1-2):82-90.

8) Schuknecht HF. Pathology of the Ear. 2nd ed. Philadelphia, USA: Lea \& Febiger;1993. p.499-523.

9) Kimura RS, Schuknecht HF. Membranous hydrops in the inner ear of the guinea pig after obliteration of the endolymphatic sac. Practica Oto-Rhino-Laryngologica 1965;27(6):343-54.

10) Guild SR. The circulation of the endolymph. Am J Anat 1927;39(1): 57-81.

11) Salt AN. Regulation of endolymphatic fluid volume. Ann N Y Acad Sci 2001;942:306-12.

12) Salt AN, Thalmann R, Marcus DC, Bohne BA. Direct measurement of longitudinal endolymph flow rate in the guinea pig cochlea. Hear Res 1986;23(2):141-51.

13) Lindsay JR. Effect of obliteration of the endolymphatic sac and duct in the monkey. Arch Otolaryngol 1947;45(1):1-13.

14) Swart JG, Schuknecht HF. Long-term effects of destruction of the endolymphatic sac in a primate species. Laryngoscope 1988;98(11): 1183-9.

15) Rask-Andersen H, Danckwardt-Lillieström N, Linthicum FH Jr, House WF. Ultrastructural evidence of a merocrine secretion in the human endolymphatic sac. Ann Otol Rhinol Laryngol 1991;100(2): $148-56$.

16) Schuknecht HF. Pathology of the Ear. 1st ed. Cambridge, USA: Harvard University Press;1974. p.459-63.

17) Tonndorf J. The machanism of hearing loss in early cases of endolymphatic hydrops. Ann Otol Rhinol Laryngol 1957;66(3):766-84.

18) Tonndorf J. Endolymphatic hydrops: mechanical cause of hearing loss. Eur Arch Otorhinolaryngol 1976;212(4):293-9.

19) Takeuchi S, Takeda T, Saito H. Pressure relationship between perilymph and endolymph associated with endolymphatic infusion. Ann Otol Rhinol Laryngol 1991;100(3):244-8.

20) Long $\mathrm{CH} 3 \mathrm{rd}$, Morizono T. Hydrostatic pressure measurements of endolymph and perilymph in a guinea pig model of endolymphatic hydrops. Otolaryngol Head Neck Surg 1987;96(1):83-95.

21) Böhmer A. Hydrostatic pressure in the inner ear fluid compartments and its effects on inner ear function. Acta Otolaryngol Suppl 1993; 507:3-24

22) Fenton RA. Essential role of vasopressin-regulated urea transport processes in the mammalian kidney. Pflugers Arch 2009;458(1): 169-77.

23) Takeda T, Taguchi D. Aquaporins as potential drug targets for Meniere's disease and its related diseases. Handb Exp Pharmacol 2009;(190):171-84.

24) Takeda T, Takeda S, Kitano H, Okada T, Kakigi A. Endolymphatic hydrops induced by chronic administration of vasopressin. Hear Res 2000;140(1-2):1-6.

25) Kwun YS, Yeo SW, Ahn YH, Lim SW, Jung JY, Kim WY, et al. Immunohistochemical localization of urea transporters A and B in the rat cochlea. Hear Res 2003;183(1-2):84-96.

26) Yamashita T, Schuknecht HF. Apical endolymphatic hydrops. Arch
Otolaryngol 1982;108(8):463-6.

27) Lau SK, Linthicum FH Jr. Apparent apical endolymphatic hydrops: computer-aided three-dimensional reconstruction and histologic study of the apical turn of the cochlear duct. Am J Otol 1993;14(1): 79-81.

28) Verhagen WI, Huygen PL, Joosten EM. Familial progressive vestibulocochlear dysfunction. Arch Neurol 1988;45(7):766-8.

29) Manolis EN, Yandavi N, Nadol JB Jr, Eavey RD, McKenna M, Rosenbaum S, et al. A gene for non-syndromic autosomal dominant progressive postlingual sensorineural hearing loss maps to chromosome 14q12-13. Hum Mol Genet 1996;5(7):1047-50.

30) Robertson NG, Lu L, Heller S, Merchant SN, Eavey RD, McKenna $\mathrm{M}$, et al. Mutations in a novel cochlear gene cause DFNA9, a human nonsyndromic deafness with vestibular dysfunction. Nat Genet 1998;20(3):299-303.

31) Verstreken M, Declau F, Wuyts FL, D'Haese P, Van Camp G, Fransen E, et al. Hereditary otovestibular dysfunction and Ménière's disease in a large Belgian family is caused by a missense mutation in the COCH gene. Otol Neurotol 2001;22(6):874-81.

32) Fransen E, Verstreken M, Verhagen WI, Wuyts FL, Huygen PL, D'Haese P, et al. High prevalence of symptoms of Menière's disease in three families with a mutation in the $\mathrm{COCH}$ gene. Hum Mol Genet 1999;8(8):1425-9.

33) Usami S, Takahashi K, Yuge I, Ohtsuka A, Namba A, Abe S, et al. Mutations in the $\mathrm{COCH}$ gene are a frequent cause of autosomal dominant progressive cochleo-vestibular dysfunction, but not of Meniere's disease. Eur J Hum Genet 2003;11(10):744-8.

34) Merchant SN. Schuknecht's Pathology of the Ear, 3rd ed. In: Merchant SN, Nadol JB Jr, editors. Genetically Determined and Other Develpmental Defects. Shelton: PMPH-USA Inc; 2010. p.141-277.

35) Alport AC. Hereditary familial congenital hemorrhagic nephritis. Br Med J 1927;(13454):504-6.

36) Colville D, Savige J. Albipunctatus retinopathy in inherited interstitial nephritis. Aust N Z J Ophthalmol 1994;22(4):267-9.

37) Fujita S, Hayden RC Jr. Alport's syndrome. Temporal bone report. Arch Otolaryngol 1969;90(4):453-66.

38) Merchant SN, Burgess BJ, Adams JC, Kashtan CE, Gregory MC, Santi PA, et al. Temporal bone histopathology in alport syndrome. Laryngoscope 2004;114(9):1609-18.

39) Schuknecht HF. Pathology of the ear. $2^{\text {nd }}$ ed. Infection. Philadelphia: Lea \& Febiger;1993. p.191-253.

40) Linthicum FH Jr, el-Rahman AG. Hydrops due to syphilitic endolymphatic duct obliteration. Laryngoscope 1987;97(5):568-74.

41) Miller ME, Makary C, Lopez IA, Ishiyama A. Endolymphatic hydrops in otologic syphilis: a temporal bone study. Otol Neurotol 2010; 31(4):681-6.

42) Pulec JL. Meniere's disease: results of a two and one-half-year study of etiology, natural history, and results of treatment. Laryngoscope 1972;82(9):1703-15.

43) Clark SK, Rees TS. Posttraumatic endolymphatic hydrops. Arch Otolaryngol 1977;103(12):725-6.

44) Rizvi SS, Gibbin KP. Effect of transverse temporal bone fracture on the fluid compartment of the inner ear. Ann Otol Rhinol Laryngol 1979;88(Pt 1):741-8.

45) Lyos AT, Marsh MA, Jenkins HA, Coker NJ. Progressive hearing loss after transverse temporal bone fracture. Arch Otolaryngol Head Neck Surg 1995;121(7):795-9.

46) Belal A Jr, Ylikoski J. Poststapedectomy dizziness. A histopathologic report. Am J Otol 1982;3(3):187-91.

47) Handzel O, Burgess BJ, Nadol JB Jr. Histopathology of the peripheral vestibular system after cochlear implantation in the human. Otol Neurotol 2006;27(1):57-64.

48) Cmejrek RC, Megerian CA. Obstructing lesions of the endolymphatic sac and duct mimicking Ménière's disease. Ear Nose Throat 
J 2004;83(11):753-6.

49) Butman JA, Kim HJ, Baggenstos M, Ammerman JM, Dambrosia J, Patsalides A, et al. Mechanisms of morbid hearing loss associated with tumors of the endolymphatic sac in von Hippel-Lindau disease. JAMA 2007;298(1):41-8.

50) Lonser RR, Kim HJ, Butman JA, Vortmeyer AO, Choo DI, Oldfield EH. Tumors of the endolymphatic sac in von Hippel-Lindau disease. N Engl J Med 2004;350(24):2481-6.

51) Mahmud MR, Khan AM, Nadol JB Jr. Histopathology of the inner ear in unoperated acoustic neuroma. Ann Otol Rhinol Laryngol 2003;112(11):979-86.

52) Adams JC. Clinical implications of inflammatory cytokines in the cochlea: a technical note. Otol Neurotol 2002;23(3):316-22.

53) Donne A. Cours de microscopie complémentaire des études médicales: anatomie microscopique et physiologie des fluides de l'économie. Paris, France: JB Baillière;1844.

54) Politzer A. Pathologische Veranderungen im Labyrinthe bei leukamischer Taubheit. Cong Int Otol 1885;3:139.

55) Sando I, Egami T. Inner ear hemorrhage and endolymphatic hydrops in a leukemic patient with sudden hearing loss. Ann Otol Rhinol Laryngol 1977;86(4 Pt 1):518-24.

56) Yoo TJ, Stuart JM, Kang AH, Townes AS, Tomoda K, Dixit S. Type II collagen autoimmunity in otosclerosis and Meniere's disease. Science 1982;217(4565):1153-5.

57) Yoo TJ, Tomoda K, Stuart JM, Cremer MA, Townes AS, Kang AH. Type II collagen-induced autoimmune sensorineural heareing loss and vestibular dysfunction in rats. Ann Otol Rhinol Laryngol 1983; 92(3 Pt 1):267-71.

58) Hughes GB, Barna BP, Kinney SE, Calabrese LH, Hamid MA, Nalepa NJ. Autoimmune endolymphatic hydrops: five-year review. Otolaryngol Head Neck Surg 1988;98(3):221-5.

59) Jenkins HA, Pollak AM, Fisch U. Polyarteritis nodosa as a cause of sudden deafness. A human temporal bone study. Am J Otolaryngol 1981;2(2):99-107.

60) Gussen P. Polyarteritis nodosa and deafness. A human temporal bone study. Arch Otorhinolaryngol 1977;217(3):263-71.

61) Yanagita N, Yokoi H, Koide J, Toriyama M, Ishii T. Acute bilateral deafness with nephritis: a human temporal bone study. Laryngoscope 1987:97(3 Pt 1):345-52.

62) Yoon TH, Paparella MM, Schachern PA. Systemic vasculitis: a temporal bone histopathologic study. Laryngoscope 1989;99(6 Pt 1): 600-9.

63) Schuknecht HF, Nadol JB Jr. Temporal bone pathology in a case of Cogan's syndrome. Laryngoscope 1994;104(9):1135-42.

64) Ishii T, Watanabe I, Suzuki J. Temporal bone findings in Cogan's syndrome. Acta Otolaryngol Suppl 1995;519:118-23.

65) Fisher ER, Hellstrom HR. Cogan's syndrome and systemic vascular disease. Analysis of athologic features with reference to its relationship to thromboangiitis obliterans (Buerger). Arch Pathol 1961;72: 572-92.

66) Woff D, Bernhard WG, Tsutsumi S, Ross IS, Nussbaum HE. The pa- thology of Cogan's syndrome causing profound deafness. Ann Otol Rhinol Laryngol 1965;74:507-20.

67) Rarey KE, Bicknell JM, Davis LE. Intralabyrinthine osteogenesis in Cogan's syndrome. Am J Otolaryngol 1986;7(6):387-90.

68) Kariya S, Fukushima K, Kataoka Y, Tominaga S, Nishizaki K. Innerear obliteration in ulcerative colitis patients with sensorineural hearing loss. J Laryngol Otol 2008;122(8):871-4.

69) Morís G, Milla A, Ribacoba R, González C. Acute deafness as an extraintestinal manifestation of ulcerative colitis. Eur J Intern Med 2005;16(6):440-2.

70) Nemoto H, Iguchi H, Ichikawa Y, Wakata N, Kurihara T. Ulcerative colitis presenting as sensorineural deafness, brainstem encephalopathy, and white matter lesions. Neurologist 2004;10(3):165-8.

71) Hoistad DL, Schachern PA, Paparella MM. Autoimmune sensorineural hearing loss: a human temporal bone study. Am J Otolaryngol 1998;19(1):33-9.

72) Schuknecht HF, Barber W. Histologic variants in otosclerosis. Laryngoscope 1985;95(11):1307-17.

73) Altmann F. Histopathology and etiology of otosclerosis: a critical review. In: HF Schucknecht, editor. Otosclerosis. Boston: Little Brown;1962. p.15-42.

74) Gussen R. The labyrinthine capsule: normal structure and pathogenesis of otosclerosis. Acta Otolaryngol 1968;Suppl 235:1-55.

75) Kelemen G, Linthicum FH Jr. Labyrinthine otosclerosis. Acta Otolaryngol Suppl 1969;253:1-68.

76) Yoon TH, Paparella MM, Schachern PA. Otosclerosis involving the vestibular aqueduct and Menière's disease. Otolaryngol Head Neck Surg 1990;103(1):107-12.

77) Makarem A, Linthicum FH. Cochlear otosclerosis and endolymphatic hydrops. Otol Neurotol 2008;29(4):571-2.

78) Black FO, Sando I, Hildyard VH, Hemenway WG. Bilateral multiple otosclerotic foci and endolymphatic hydrops, histopathological case report. Ann Otol Rhinol Laryngol 1969;78(5):1062-73.

79) Lindsay JR, Suga F. Paget's disease and sensori-neural deafness: temporal bone histopathology of Paget's disease. Laryngoscope 1976;86 (7):1029-42.

80) Nager GT. Paget's disease of the temporal bone. Ann Otol Rhinol Laryngol 1975;84(4 Pt 3 Suppl 22):1-32.

81) Khetarpal U, Schukecht HF. In search of pathologic correlates for hearing loss and vertigo in Paget's disease. A clinical and histopathologic study of 26 temporal bones. Ann Otol Rhinol Laryngol Suppl 1990;145;1-16.

82) Nager GT. Osteitis Deformans Paget. In: Nager GT, edit. Pathology of the Ear and Temporal Bone. Baltimore: Williams \& Wilkins;1993. p.1011-50.

83) Teufert KB, Linthicum F Jr. Paget disease and sensorineural hearing loss associated with spiral ligament degeneration. Otol Neurotol 2005;26(3):387-91; discussion 391.

84) Linthicum FH. Histopathology of Meniere's-like conditions. In Harris JP, ed. Ménière's Disease. The Hague, The Netherlands: Kugler Publications;1999. p.53-66. 